\title{
CORRECTION
}

\section{Treating iron deficiency}

CMAJ has been made aware of an error that occurred in the Mar. 13, 2017, issue. ${ }^{1}$

The first sentence of the last paragraph included the formula "(weight in $\mathrm{kg} \times[(150$ - current hemoglobin in $\mathrm{g} / \mathrm{L}) \div$ $100] \times 2.4+500)$." The formula should have been "(weight in $\mathrm{kg} \times[(150-$ current hemoglobin in $\mathrm{g} / \mathrm{L}) \div 10] \times 2.4+500$ )."

This has been corrected at cmaj.ca.

- Cite as: CMAJ 2017 September 18;189: E1198. doi: 10.1503/cmaj.170971

\section{Reference}

1. Zeller MP, Verhovsek M. Treating iron deficiency. CMAJ 2017;189:E409. 